\title{
Levels of Essential Elements and Anions in Vegetables from Organic Matter Impacted Farm in Uyo, Nigeria
}

\author{
Godwin Asukwo Ebong*, Helen Solomon Etuk \\ Department of Chemistry, University of Uyo, Uyo, Nigeria \\ Email address: \\ g_ebong@yahoo.com (G. A. Ebong), goddyebong2010@gmail.com (G. A. Ebong), helenetuk.etuk@yahoo.com (H. S. Etuk) \\ *Corresponding author
}

\section{To cite this article:}

Godwin Asukwo Ebong, Helen Solomon Etuk. Levels of Essential Elements and Anions in Vegetables from Organic Matter Impacted Farm in Uyo, Nigeria. American Journal of Biological and Environmental Statistics. Vol. 3, No. 2, 2017, pp. 20-25. doi: 10.11648/j.ajbes.20170302.11

Received: January 8, 2017; Accepted: January 24, 2017; Published: October 31, 2017

\begin{abstract}
Fresh leaves of vegetables widely utilized for their nutritional and medicinal benefits in Nigeria namely: Telfairia occidentalis, Heinsia crinata, Vernonia amygdelina, Lasienthera africana, Talinum triangulare and Gnetum africana were obtained from an organic matter impacted farm in Uyo, Nigeria. These samples were treated following standard analytical procedures and analysed using atomic absorption spectrophotometric methods for the concentrations of $\mathrm{Fe}, \mathrm{Cu}, \mathrm{Zn}, \mathrm{NO}_{2}^{-}, \mathrm{NO}_{3}{ }^{-}$ and $\mathrm{PO}_{4}{ }^{3-}$. Results obtained indicated the following ranges $\left(\mu g g^{-1}\right): 171.10-406.66 ; 5.16-6.81 ; 8.00-10.86 ; 88.40-243$. 32; $110.40-343.25$ and $163.60-422.00$ for $\mathrm{Fe}, \mathrm{Cu}, \mathrm{Zn}, \mathrm{NO}_{2}{ }^{-}, \mathrm{NO}_{3}{ }^{-}$and $\mathrm{PO}_{4}{ }^{3-}$ respectively. This study revealed that, Telfairia occidentalis has high potential of accumulating iron; Gnetum africana has the ability of absorbing more $\mathrm{Cu}$ and $\mathrm{Zn}$; Talinum triangulare is capable of absorbing high $\mathrm{NO}_{2}^{-}$and $\mathrm{NO}_{3}{ }^{-}$while Lasienthera africana has potential of absorbing more $\mathrm{PO}_{4}^{3-}$ from the soil. However, the concentrations of all the parameters determined except nitrite in Talinum triangulare were within their safe limits recommended by WHO. This research work has also established that, the application of organic manure in agricultural soils is recommended provided the soil and sources of organic matter are not polluted.
\end{abstract}

Keywords: Vegetables, Organic Matter, Nigeria, Essential Elements, Anions and Pollutants

\section{Introduction}

Anthropogenic activities aimed at improving the quality of life on earth have adversely affected the concentration of chemical substances in soil higher than their natural levels; thereby making them toxic to plants grown on them and subsequently creating serious problems along the food chain. Studies have shown that leafy vegetables have the potential of accumulating very high concentrations of metals and other toxic chemicals from contaminated soil and transferring same into the food chain $[1,2,3]$. The roles of leafy vegetables in nutrition and traditional medicine in Nigeria are enormous [4, $5,6]$. Consequently, most people in developing countries of the world depend on leafy vegetables as a source of mineral elements and as antidote to their health challenges thereby increasing the population of those consuming vegetables. Phosphate, nitrate and nitrite are natural components of soil and vegetables as a consequence of elemental cycles; though their levels in vegetables are greatly influenced by vegetable type, source, condition of cultivation and storage [7]. It has also been reported that, the application of fertilizers and other agrochemicals for improved output has elevated concentrations of metals and anions in vegetables grown on them $[8,9,10]$. Notwithstanding the intensive application of agrochemicals and extensive utilization of leafy vegetables, the quality of soils on which they are grown on and levels of toxic chemicals accumulated in them are not given the much attention deserved. Accordingly, consumption of vegetables grown on contaminated soils may result in accumulation of metals, anions and other toxic chemicals, thereby creating associated health consequences along the food chain $[11,12$, 13]. It is therefore imperative to assess the quality of vegetables widely consumed by the populace to forestall impending disaster that may arise as reported by Xian [14]. This study aimed at evaluating the concentration of anions and essential elements in leafy vegetables obtained from a farm in Uyo, Akwa Ibom state which has been exposed to intensive applications of organic manure. Results obtained from this study will expose the suitability or otherwise of 
vegetables and health implications associated with the consumption of vegetables from studied farm and other farm exposed to organic manure.

\section{Materials and Methods}

\section{Sample Collection and Treatment}

Matured and leaves of Telfeiria occidentalis, Heinsia crinata, Gnetum africana, Lasienthera africana, Veronia amygdalina and Talinum triangulare were randomly collected from a farm in Itiam village in Uyo, Akwa Ibom State, Nigeria. Fresh leaves of the studied vegetables were obtained using stainless steel knife following the methods of Radojevic and Bashkin [15]. Samples collected were washed first with tap water and later with distilled water to remove debris deposited on them. Vegetable samples obtained were oven dried at $104^{\circ} \mathrm{C}$ for 24 hours, ground and sieved.

\section{Sample Digestion and Trace Metal Analysis}

$1 \mathrm{~g}$ of each sieved vegetable sample in an acid-washed porcelain crucible was placed in a muffle furnace for four (4) hours at $500^{\circ} \mathrm{C}$. The crucible was later removed from the furnace and cooled. $10 \mathrm{ml}$ of $6 \mathrm{M} \mathrm{HCl}$ was added covered and heated on a steam bath for 15 minute, then I ml of $\mathrm{HNO}_{3}$ added and evaporated to dryness. For complete dissolution of samples, $5 \mathrm{ml}$ of $6 \mathrm{M} \mathrm{HCl}$ and $10 \mathrm{ml}$ of distilled water were finally added and the mixture heated on a steam bath. The mixture was cooled and filtered into a $50 \mathrm{ml}$ volumetric flask and made up to mark with distilled water (15). Concentrations of iron, copper and zinc in studied vegetables were determined using atomic absorption spectrophotometer (Pye Unicam SPQ) model.

\section{Determination of Nitrate and Nitrite}

For the determination of nitrate and nitrite, to $1 \mathrm{~g}$ of each fresh vegetable sample in a $100 \mathrm{ml}$ flask, $50 \mathrm{ml}$ of distilled water was added, shaken for 30 minutes. The mixture was filtered into another $100 \mathrm{ml}$ volumetric flask and made to mark with distilled water [15]. Concentrations of nitrate and nitrite were determined using grating spectrophotometer SE
2343 model.

\section{Determination of Phosphate}

Concentration of phosphate in each of the vegetable samples was determined by cutting the vegetables into small pieces and air-dried for three (3) days; ground and sieved. $1 \mathrm{~g}$ of each of the sieved samples was weighed into acid-washed porcelain crucibles. To each crucible, $5 \mathrm{ml}$ of $20 \%(\mathrm{w} / \mathrm{v})$ magnesium acetate was added and evaporated to dryness. These crucibles were transferred into a muffle furnace at $500^{\circ} \mathrm{C}$ for four (4) hours, removed and cooled. $10 \mathrm{ml}$ of $6 \mathrm{M}$ $\mathrm{HCl}$ was then added to each of the crucible and heated on a steam bath for 15 minutes. The content of each crucible was transferred into evaporating dish, $1 \mathrm{ml}$ of Conc. $\mathrm{HNO}_{3}$ added and heated for 1 hour. $1 \mathrm{ml}$ of $6 \mathrm{M} \mathrm{HCl}$ was added to the mixture, shaken then $10 \mathrm{ml}$ of distilled water added and heated on a steam bath. The content of the evaporating dish was cooled, filtered into a $50 \mathrm{ml}$ volumetric flask and made to mark with distilled water [15]. Phosphate levels in studied vegetables were determined using grating spectrophotometer SE 2343 model.

\section{Statistical Analysis}

IBM SPSS Statistics 20 model was employed for the analysis of mean, standard deviation, kurtosis and Pearson correlation coefficients.

\section{Quality Assurance}

To guarantee the reliability, accuracy and reproducibility of our findings, standard analytical techniques were employed and reagents used were of high percentage purity. Precautions were taken to minimized or if possible eliminate errors that would have accompanied the procedures.

\section{Results and Discussion}

Results for the concentration of iron, copper, zinc, nitrate, nitrite and phosphate in the different vegetables studied are shown in Table 1. Table 2 gives the correlation coefficients of trace metals and anions in studied vegetables.

Table 1. *Concentration $\left(\mu \mathrm{gg}^{-1}\right)$ of essential micro elements and anions in vegetables commonly consumed in Akwa Ibom State, Nigeria.

\begin{tabular}{|c|c|c|c|c|c|c|}
\hline SAMPLE & $\mathbf{F e}$ & $\mathrm{Cu}$ & Zn & $\mathrm{NO}_{2}^{-}$ & $\mathrm{NO}_{3}^{-}$ & $\mathrm{PO}_{4}{ }^{3-}$ \\
\hline Telfairia occidentalis & 406.66 & 5.16 & 8.00 & 88.40 & 110.40 & 171.60 \\
\hline Heinsia crinata & 171.10 & 5.63 & 8.58 & 158.00 & 231.20 & 201.60 \\
\hline Vernonia amygdelina & 206.66 & 5.80 & 9.16 & 200.00 & 298.80 & 304.80 \\
\hline Lasienthera africana & 373.32 & 5.57 & 9.14 & 212.40 & 292.40 & 422.00 \\
\hline Talinum triangulare & 351.10 & 6.15 & 8.53 & 243.32 & 343.25 & 401.20 \\
\hline Gnetum africana & 217.76 & 6.81 & 10.86 & 91.00 & 124.47 & 163.60 \\
\hline Minimum & 171.10 & 5.16 & 8.00 & 88.40 & 110.40 & 163.60 \\
\hline Mean & 287.77 & 5.85 & 9.05 & 165.52 & 233.43 & 277.47 \\
\hline Standard Deviation & 100.56 & 0.57 & 0.99 & 64.80 & 96.77 & 115.65 \\
\hline Kurtosis & -2.68 & 1.02 & 2.65 & -1.92 & -1.89 & -2.34 \\
\hline
\end{tabular}

* Mean of three determinations. 
Iron is essential for synthesis of chlorophyll and responsible for the production of some respiratory related enzymes in plants. Deficiency of iron in plants may result in chlorosis of leaves and stunted growth [16]. However, high content in plant can cause bronzing and stippling of leaves. Concentrations of iron in leafy vegetables studied ranged between $171.10 \mu \mathrm{gg}^{-1}$ and $406.66 \mu \mathrm{gg}^{-1}$. The highest level of iron was recorded in Telfairia occidentalis while Heinsia crinata indicated the lowest concentration of iron. The mean concentration of iron recorded for all the studied vegetables $\left(287.77 \pm 100.56{\mu g^{-1}}^{-1}\right)$ is lower than $425.00 \mathrm{mgkg}^{-1}$ stipulated by $\mathrm{FAO} / \mathrm{WHO}$ [17]. Consequently, application of organic manure may not have elevated concentration of iron to a level higher than that desired by vegetables grown there. Thus, these vegetables could be good supplement for iron in human body. The level of iron in studied vegetables is much higher than $0.21-3.54 \mathrm{mg} / \mathrm{kg}$ reported in vegetables from Northern part of Nigeria by Akan et al. [8]. Nevertheless, the range $\left(73.30-516.30 \mu \mathrm{gg}^{-1}\right)$ recorded in vegetables from Saudi Arabia by Ali and Al-Qahtani [18] is higher than that reported in this study. Concentrations of iron in the different vegetables studied followed platykurtic distribution since the kurtosis is less than zero $(-2.68)$.

Copper is required for proper plant growth though at very low concentration however; higher levels of copper have been reported in vegetables. Copper concentrations in studied vegetables varied between $5.16 \mu \mathrm{gg}^{-1}$ in Telfairia occidentalis and $6.81 \mu \mathrm{gg}^{-1}$ obtained in Gnetum Africana. The obtained range is higher than $1.220-5.220 \mu \mathrm{g} / \mathrm{g}$ reported for copper in vegetables from middle belt of Nigeria by Raphael and Adebayo [11] but lower than $22.19-76.50 \mathrm{mg} / \mathrm{kg}$ obtained by Demirezen and Ahmet [19] in leafy vegetables from Turkey. The mean copper concentration obtained $\left(5.85 \pm 0.57 \mu \mathrm{gg}^{-1}\right)$ is below $73.00 \mathrm{mg} / \mathrm{kg}$ recommended for leafy vegetables by FAO/WHO [17]. This study has shown that, organic matter applied to improve plant yield may not have polluted the soil environment with copper. However, copper concentrations in studied vegetables could have been essential for normal enzymatic activities and plant growth as reported by Raven et al. [20]. Consumption of these vegetables may have been a good source of copper for human. Copper concentration varied from one vegetable to the other and recorded a kurtosis value of 1.02 which is a leptokurtic distribution.

Zinc concentrations in studied vegetables varied between $8.00 \mu \mathrm{gg}^{-1}$ and $10.8 \mu \mathrm{gg}^{-1}$; the highest concentration was recorded in Gnetum africana while zinc concentration in Telfairia occidentalis was the lowest obtained. This range is consistent with that reported by Rapheal and Adebayo [11] in vegetables from Makurdi but higher than $0.11-1.44 \mathrm{mgkg}^{-}$ 1 obtained in vegetables from Maiduguri, Nigeria. However, this range is lower than $21.54-35.54 \mu \mathrm{gg}^{-1}$ reported by Ali and Al-Qahtani [18] in vegetables from Saudi Arabia. The mean concentration of zinc $\left(9.05 \pm 0.99 \mu \mathrm{gg}^{-1}\right)$ is much lower than $99.40 \mathrm{mgkg}^{-1}$ stipulated for leafy vegetables by FAO/WHO [17]. This study therefore revealed that, farm inputs applied may not have impacted negatively on the level of zinc in studied vegetables. Consequently, concentrations of zinc in the studied vegetables could be functional for their growth and normal enzymatic activities as indicated by Hafeez et al. [21]. Zinc indicated a leptokurtic distribution pattern in vegetables studied with kurtosis value of 2.65.

Nitrite concentrations in studied vegetables varied from $88.40 \mu \mathrm{g} / \mathrm{g}$ reported in Telfairia occidentalis to $243.32 \mu \mathrm{gg}^{-1}$ obtained in Talinum triangulare. This range is higher than $8.18-199.42 \mu \mathrm{gg}^{-1}$ obtained in samples from Borno State, Nigeria by Uwah et al. [22]. The range is also dissimilar with $33.00-478.00 \mu \mathrm{gg}^{-1}$ reported in Kano, Nigeria by Akan et al. [23]. The high nitrite in studied vegetables may be attributed to excessive application of nitrate fertilizers and organic manure to improve their yield and high nitrate content in the area [24, 25]. This is in agreement with the report by Santamaria et al. [26] that leafy vegetables contain high level of nitrite. The mean concentration of nitrite in all studied vegetables except Telfairia occidentalis and Gnetum Africana were above $100.00 \mathrm{mgkg}^{-1}$ recommended for leafy vegetables by WHO [27]. This has shown that, organic matter applied to improve plant yield may have increased the nitrite level substantially. Consequently, prolong consumption of these vegetables may result in infantile methemoglobinemia in young children; headache, dizziness, vomiting and diarrhea in adults $[28,29]$. The variation of nitrite concentrations from one vegetable to the other followed a platykurtic distribution as indicated by kurtosis value of -1.92 .

Nitrate is natural component of the environment as a consequence of nitrogen fixation however; the concentration in plants has been greatly elevated by the modern farming practices. Concentrations of nitrate in studied vegetables ranged between $110.40 \mu \mathrm{gg}^{-1}$ recorded in Telfairia occidentalis and $343.25{\mu \mathrm{gg}^{-1}}^{-1}$ obtained in Talinum triangulare. This is above $110.00-178.00 \mu \mathrm{gg}^{-1}$ reported by Akan et al. [30] in vegetables from Kano, Nigeria but lower than 91.00 - $3428.00 \mu \mathrm{gg}^{-1}$ obtained in vegetables from Turkey by Mor et al. [31]. Generally, the mean obtained $\left(233.43 \pm 96.77 \mathrm{gg}^{-1}\right)$ is within the limit of $2500 \mathrm{mgkg}$ ${ }^{1}$ recommended for leafy vegetables by WHO [27]. Organic materials in the farm could have contributed nitrate level that may not pose a problem to those consuming vegetables obtained from the studied farm. Consequently, concentrations of nitrate in studied vegetables could be essential for tissue development [32]. Variations of nitrate concentrations among studied vegetables followed a platykurtic distribution with kurtosis value of -1.89 .

Phosphate in studied vegetables varied from $163.60 \mu \mathrm{gg}^{-1}$ in Gnetum africana to $422.00 \mu_{\mathrm{gg}^{-1}}$ obtained in Lasienthera africana. This is higher than $2.897-3.342 \mathrm{mgkg}^{-1}$ and 32.00 $-73.00 \mu \mathrm{gg}^{-1}$ reported in Kenya by Wamalwa et al. [33] and in vegetables from Kano, Nigeria by Akan et al. [30] respectively. The high phosphate levels in studied vegetables could be attributed to the application of organic manure in the farm and the nature of the parent material from which the soil was formed $[34,35]$. Nevertheless, the mean phosphate 
level obtained $\left(277.47 \pm 115.65 \mu \mathrm{gg}^{-1}\right)$ is lower than 5000 $\mathrm{mgkg}^{-1}$ stipulated by WHO [27] for leafy vegetables. Consequently, phosphate in studied vegetables could be essential for normal plant photosynthetic, growth and reproductive processes [34]. Accordingly, phosphate level contributed by organic matter applied to the farm has not reached the nuisance level. Consumption of vegetables with the reported phosphate concentrations aid in the formation of bones and teeth, kidney functioning, muscle contraction, normal heartbeat and nerve signaling in human [35]. However, bioaccumulation of phosphate in the underlying soil should be avoided to forestall incidences such as hyperphoshatemia, hypocalcaemia, osteoporosis and soft tissues calcinosis in consumers of vegetables grown on the soil [36, 37]. Results obtained for phosphate concentrations in studied vegetables followed a platykurtic distribution as indicated by Kurtosis value of -2.34 .

\section{Correlation Studies of Parameters Determined in Studied Vegetables}

Table 2. Pearson correlation coefficients among parameters in studied vegetables.

\begin{tabular}{lllllll}
\hline & $\mathbf{F e}$ & $\mathbf{C u}$ & $\mathbf{Z n}$ & $\mathbf{N O}_{2}{ }^{-}$ & $\mathbf{N O}_{3}{ }^{-}$ & $\mathbf{P O}_{4}{ }^{3-}$ \\
\hline $\mathrm{Fe}$ & 1.000 & & & & & \\
$\mathrm{Cu}$ & -0.435 & 1.000 & & & & \\
$\mathrm{Zn}$ & -0.464 & $0.846^{*}$ & 1.000 & & & \\
$\mathrm{NO}_{2}{ }^{-}$ & 0.094 & -0.044 & -0.259 & 1.000 & & \\
$\mathrm{NO}_{3}{ }^{-}$ & -0.001 & -0.022 & -0.233 & $0.995^{*}$ & 1.000 & \\
$\mathrm{PO}_{4}{ }^{3-}$ & 0.382 & -0.074 & -0.188 & $0.922^{*}$ & $0.885^{*}$ & 1.000 \\
\hline
\end{tabular}

*Significant at $\mathrm{P}<0.01$

Weak negative correlations were recorded for the pairs Fe$\mathrm{Cu}$ and $\mathrm{Fe}-\mathrm{Zn}$ with $\mathrm{r}$ values of -0.435 and -0.464 respectively at $99 \%$ confidence limit. This study indicated that, there was no linear association at $\mathrm{P}<0.01$ between the following pairs: Fe- $\mathrm{NO}_{2}{ }^{-}$and $\mathrm{Fe}_{-} \mathrm{NO}_{3}{ }^{-}$with $\mathrm{r}$ values of 0.094 and -0.001 respectively. However, iron indicated a weak positive correlation with phosphate at $\mathrm{P}<0.01$ with correlation coefficient of 0.382. Consequently, the parameters determined in studied vegetables may have emanated from different sources and their chemical properties may be different from that of iron [38, 39]. Copper exhibited no linear relationship with nitrite, nitrate and phosphate at $\mathrm{P}<$ 0.01 wth $r$ values of $-0.044 ;-0.022$ and -0.074 respectively. Thus, these properties may have originated from sources different from copper in the studied vegetables. Nevertheless, strong positive correlation was recorded for the relationship between copper and zinc indicating that these metals may have originated from a common source in the studied vegetables. The common source of copper and zinc may be attributed to organic manure in the farm as reported by Shayler et al. [40]. Zinc indicated no linear association with nitrite, nitrate and phosphate at $\mathrm{P}<0.01$ with correlation coefficients of $-0.259 ;-0.233$ and -0.188 respectively. Hence, these parameters originated from sources different from zinc. Nitrite correlated perfectly and positively with nitrate at $\mathrm{P}<$
0.01 with $\mathrm{r}=0.995$. nitrite also exhibited strong positive association with phosphate in studied vegetables at $\mathrm{P}<0.01$ $(\mathrm{r}=0.922)$. Thus, organic manure applied to the farm may have resulted in the accumulation of nitrite, nitrate and phosphate in studied vegetables [41]. Results obtained in Table 2 also revealed that, nitrate correlated positively and significantly with phosphate at $\mathrm{P}<0.01$ with $\mathrm{r}=0.885$. This corroborated with the findings by Masime et al. [41] that, application of organic manure in a farmland could attribute to high levels of nitrate and phosphate in plants grown on the farm.

\section{Conclusion}

This study has exposed the quality of vegetables obtained from the farm investigated and has also shown that, the application of organic manure to our farms may not pose any seroius health or environmental threat. However, the soil quality and source of organic manure may affect the quality of vegetables hence, periodic quality assessment of vegetables is encouraged. A comparison of our results with the ones from mechanized farms has shown that, inorganic fertilizers and other agrochemicals can affect the quality of vegetables from such farms. Mechanized farming may introduced serious environmental and health problems to our society if not properly managed and controlled.

\section{References}

[1] Al-Jassir, M. S. Shaker, A. and Khaliq, M. A. (2005). Deposition of heavy metals on green leafy vegetables sold on roadsides of Riyadh City, Saudi Arabia. Bulletin of Environmental Contamination and Toxicology, 75: 10201027.

[2] Benson, N. U. and Ebong, G. A. (2005). Heavy metals in vegetables commonly grown in atropical garden ultisol. J. Sustain. Trop. Agric. Res., 16: 77-80.

[3] Radwan, M. A. and Salama, A. K. (2006). Market basket survey for some heavy metals in Egyptian fruits and vegetables. Food Chemistry and Toxicology, 44: 1273-1278.

[4] D'Mello, J. P. F. (2003). Food Safety, ontamination and Toxins, CABI publishing, Wallingford, Oxon, UK, Cambridge, M. A. p. 480.

[5] Hamowa, A. (1994). Pharmacological studies on Vernonia amygdalina. Vet. Med. J., 42(1): 19-97.

[6] Kalagbor, I. A., Barisere, V., Barivule, G., Barile, S. and Bassey, C. (2014). Investigation of the presence of some heavy metals in four edible vegetables, bitter leaf (Vernonia amygdalina), scent leaf (Ocimum gratissimum), water leaf (Talinum triangulare) and fluted pumpkin (Telfairia occidentalis) from a cottage farm in Port Harcourt. Research Journal of Environmental and Earth Sciences 6 (1): 18-24.

[7] Gangolli, S. D., van den Brandt, P., Feron, V., Janzowsky, C., Koeman, J., Speijers, G., Speigelhalder, B., Walker, R. and Winshnok, J. (1994). Assessment of nitrate, nitrite and Nnitroso compounds. Eur J. Pharmacol Environ Toxicol Pharmacol Sect., 292: 1-38. 
[8] Akan, J. C., Kolo, B. G., Yikala, B. S. and Ogugbuaja, V. O. (2013). Determination of some heavy metals in vegetable samples from Biu local government area, Bornu State, North Eastern Nigeria. International Journal of Environmental Monitoring and Analysis, 1 (2): 40-46.

[9] Ihekeronye, A. I. and Ngoddy, P. O. (1985). "Integrated Food Science and Technology for the Tropics. Macmillan Education Ltd, Oxford and London”. p. 293.

[10] McCall, D. and Willumsen, J. (1998). Effects of nitrate, ammonium and chloride application on the yield and nitrate content of soil-grown lettuce. J. Hortic. Sci. Biotech., 73: 698703 .

[11] Rapheal, O. and Adebayo, K. S. (2011). Assessment of trace heavy metal contaminations of some selected vegetables irrigated with water from River Benue within Makurdi Metropolis, Benue State, Nigeria. Advances in Applied Science Research, 2 (5): 590-601.

[12] Sharma, R. K., Agrawal, M. and Marshall, F. M. (2008a). "Heavy metal $(\mathrm{Cu}, \mathrm{Zn}, \mathrm{Cd}$ and $\mathrm{Pb})$ contamination of vegetables in urban India: A case study in Varanasi". Environmental Pollution, 154: 254-263.

[13] Sharma, R. K., Agrawal, M. and Marshall, F. M. (2008b). "Atmospheric deposition of heavy metals $(\mathrm{Cu}, \mathrm{Zn}, \mathrm{Cd}$ and $\mathrm{Pb})$ in varanasi City, India". Environmental Monitoring Assessment, 142: 269-278.

[14] Xian, X. (1989). Effects of chemical forms of cadmium, zinc and lead in polluted soils on their uptake by cabbage plants. Plant and Soil, 113: 257-264.

[15] Radojevic, M. and Bashkin, N. V. (1999). Practical Environmental Analysis. Royal Society of Chemistry and Thoma Graham House, Cambridge, pp. 180 -430.

[16] Shuaibu, I. K., Yahaya, M. and Abdullahi, U. K. (2013). Heavy metal levels in selected green leafy vegetables obtained from Katsina Central Market, Katsina, North-Western Nigeria. African Journal of Pure and Applied Chemistry, 7(5): 179183.

[17] FAO/WHO, Codex Alimentarius Commission (2001). Food Additives and Contaminants. Joint FAO/WHO Food Standards programme, ALINORM 01/12A: 1-289.

[18] Ali, M. H. H. and Al-Qahtani, K. M. (2012). Assessment of some heavy metals in vegetables, cereals and fruits in Saudi Arabian Markets. Egyptian Journal of Aquatic Research, 38: $31-37$.

[19] Demirezen, D. and Ahmet, A. (2006). Heavy metal levels in vegetables in Turkey are within safe limits for $\mathrm{Cu}, \mathrm{Ni}$ and exceeded for $\mathrm{Cd}$ and $\mathrm{Pb}$. J. Food Qual., 29: 252 - 265.

[20] Raven, J. A., Evans, M. C. W. and Korb, R. E. (1999). The role of trace metals in photosynthetic electron transport in $\mathrm{O}_{2-}$ evolving organisms. Photosynth. Res. 60:111-149.

[21] Hafeez, B., Khanif, Y. M. and Saleem, M. (2013). Role of zinc in plant nutrition- A Review. American Journal of Experimental Agriculture, 3(2): 374-391.

[22] Uwah, E. I., Akan, J. C., Moses, E. A., Abah, J. and Ogugbuaja, V. O. (2007). Some anion levels in fresh vegetables in Maiduguri, Borno State, Nigeria. Agricultural Journal, 2(3): 392-396.
[23] Akan, J. C., Abdulrahman, F. I., Ogugbuaja, V. O. and Ayodele, J. T. (2009). Heavy metals and anion levels in some samples of vegetables grown within the vicinity of Challawa industrial area, Kano State, Nigeria. American Journal of Applied Sciences, 6 (3): 534-542.

[24] Duncan, J.G. and John, H. (2006). Effect of nitrogen fertiliser on the nitrate contents of field vegetables grown in Britain. J. Sci. Food Agric., 37: 373-383.

[25] Hardison, A., Gonzalez, P. A., Frias, I. and Raguera, J. (1996). The evaluation of the contents of nitrates and nitrites in food products for infants. J. Food. Comp. Anal., 9: 13-17.

[26] Santamaria, P., Elia, A., Serio, F. and Todaro, E. (1999). A survey of nitrate and oxalate content in retail fresh vegetables. J. Sci. Food Agri., 79: 1882-1888.

[27] WHO. (2009). Nitrates, nitrites and N-nitrosomas compounds. Geneva. Environmental Health Criteria 5.

[28] Agency for toxic substances and disease Registry (ATSDR) (2015). Public Health Statement: Nitrate and Nitrite: Division of Toxicology and Human Health Sciences.

[29] Ezeagu, I. E. (1996). Nitrate and nitrite contents in ogi and the changes occurring duringstorage. Food Chem., 56: 77-79.

[30] Akan, J. C., Abdulrahman, F. I., Damari, G. A. and Ogunbuaja, V. O. (2008). Physicochemical determination of pollutants in wastewater and vegetable samples along the Jakara wastewater channel in Kano metropolis, Kano State, Nigeria. Eur. J. Sci. Res., 23 (1): 122-133.

[31] Mor, F., Sahindokuyucu, F. and Erdogan, N. (2010). Nitrate and nitrite contents in some vegetables consumed in South Province of Turkey. Journal of Animal and veterinaryAdvances, 9 (15): 2013-2016.

[32] Groffman P. M., Daniel J. B., Lawrence, E. B., Kenneth, T. B., Grace, S., Brush, J. Morgan, G., Richard, V. P., Ian, C. Y. and Wayne C. Z. (2003). Down by the Riverside: Urban Riparian Ecology. Frontiers in Ecology and the Environment, 1(6): 315-321.

[33] Wamalwa, K. W., Lusweti, J., Lutta, S., Anditi, B. C. and Martin, O. I. (2015). Variation of pollutant levels in vegetables: A case study of Kitale Municipality, Trans-Nzoia County, Kenya. Journal of Environment and Earth Science, 5 (13): 197-208.

[34] Nelson, N. and Mikkelsen, R. (2008). Meeting the phosphorus requirement on organic farms. Better Crops, 92 (1): 12-14.

[35] VanWijk, W.T.; Clemmensen, K. E.; Shaver, G. R.; Williams, M., Callaghan, T. V.; Chapin, F. S. Cornelissen, J. H. C.; Gough, L.; Hobbie, S. E.; Jonasson, S.; Lee, J. A.; Michelsen, A.; Press, M. C.; Richardson, S. J. and Rueth, H. (2004). Long-term ecosystem level experiments at Toolik Lake, Alaska and at Abisko, Northern Sweden: generalizations and differences in ecosysytem and plant type responses to global change. Global Biology, 10: 105-123.

[36] Chinn, H. J. (1981). Effect of dietary factors on skeletal integrity in adults: Calcium, phosphorus, Vitamin D and protein. FASEB Life Science Technical Report, 223-79-2 275, pp. 1-75.

[37] Draper, H. H. and Scythes, C. A. (1981). Calcium, phosphorus and osteoporosis. Fed. Pro., 40: 2434-2438. 
[38] Horsfall Jr M, Horsfall MN, Spiff AI. Speciation of heavy metals in inter-tidal sediments of the Okrika River system, Rivers State, Nigeria. Bull. Chem. Soc. Ethiop. 1998; 13(1): $1-9$.

[39] Romic M, Romic D. Heavy metal distribution in agricultural top soils in urban areas.Environmental Geology. 2002; 43:795-805

[40] Shayler, H., McBride, M. and Harrison, E. (2009). Sources and impacts of contaminants in soils. Cornell Waste Management Institute, Rice hall, Itheca, NY. pp. 1-6.
[41] Masime, J. O., Wanjau, R., Murrungi, J. and Onindo, C. (2013). A Comparison of the levels of nitrate, nitrite and phosphate in homemade brews, spirits, in water and raw materials in Nairobi County using UV-visible spectroscopy. International Journal of Scientific \& Engineering Research, 4(12): 329-344. 